The 40th Research Conference on Communication, Information and Internet Policy

Friday, September 21-Sunday, September 3, 2012

George Mason University School of Law, Arlington, VA

12 August 2012

\title{
Will they fly?: Different Forms of Public-Private Partnerships (PPPs) in New Zealand's UFB Initiative
}

Bert Sadowski

School of Innovation Sciences

University of Technology Eindhoven, The Netherlands

Bronwyn Howell

Institute for the Study of Regulation and Competition, Victoria University of Wellington, New Zealand

\begin{abstract}
Starting in October 2009 with a tender ("Invitation to Participate") procedure, the Ultra Fast Broadband (UFB) initiative the government of New Zealand intends to deliver fiber connections (i.e. $100 \mathrm{Mbps} / 50 \mathrm{Mbps}$ ) to 75 percent of New Zealanders by 2019. Broadband penetration levels in New Zealand have slowly been catching up compared to other high-income OECD economies. However, currently it seems that the contribution of the UFB initiative to broadband penetration in New Zealand is not as expected. The article discusses the industry structure in the broadband market and the effects of regulation in New Zealand and relates this discussion to developments in the broadband sector in Europe. In this context, the paper examines the different forms of PPPs in New Zealand's UFB initiative with respect to their (expected) effects on roll out of broadband in New Zealand. The paper builds on the literature on the appropriate contract choice in regulated markets (Demsetz, 1968; Williamson, 1976). Similar to Bettignies \& Ross (2004) it focuses on the extent to which the relationship-specific investment and the complexity (or uncertainty) of the exchange environment has an impact on the form of PPPs (Bettignies \& Ross, 2004; Crocker \& Masten, 1996). It examines in greater detail the task and risk allocation in the different PPPs, whereby the contracts between LFCs and CFH can be considered as a joint venture and the agreements between Chorus and CFH as more contractual forms. We conclude that problems with the UFB initiative might emerge as the demand risks are not sufficiently specified which might slow broadband adoption in New Zealand.
\end{abstract}




\section{Introduction}

Shortly after the publication of new data on broadband penetration by the OECD (OECD, 2012), a political discussion has sparked in the media in New Zealand with comments ranging from "New Zealand is going nowhere ultra-fast" (infonews.co.nz, 2012) to "Broadband uptake rises" (The Domininon Post, 2012). The low ranking of New Zealand with respect to broadband penetration in the OECD has become a political topic already before the Labour government's 2006 telecommunications industry reforms, but has since gradually climbing on the political agenda. The OECD data showed that New Zealand was in December 2011 ranked $17^{\text {th }}$ on the list of high income OECD countries ${ }^{1}$ measured in terms of broadband subscribers per 100 inhabitants (26.9 percent), just behind Japan (27.4 percent) and the United States ( 27.7 percent) but four places above Australia (24.6 percent) and slightly above the OECD average (25.6 percent) (OECD, 2012). Over the past six months since December 2011, the number for broadband connection were rising by 2.7 percent, well ahead of the OECD average increase of 1.8 per cent and well ahead of Japan's 1.2 percent rise. Currently just a small part of broadband subscriptions ( 0.31 percent) are fiber connections. That means that New Zealand still has some way to go with respect to fiber connections as it is currently lagging behind Australia (0.67 percent) (OECD, 2012). The contribution of the Ultra-Fast Broadband (UFB) initiative which promised to deliver fiber connections (i.e. $100 \mathrm{Mbps} / 50 \mathrm{Mbps}$ ) to 75 percent of New Zealanders by 2019 has to be considered in the context of this political discussion.

Similar to developments in Europe, the government of New Zealand recognized in 2008/9 that Next Generation Access (NGA) networks will become important in the development of the broadband market. The developments in Europe and New Zealand have contributed to the understanding with respect to possible migration paths, criteria for migration from traditional broadband to NGA networks and the effects of separation on NGA rollout. In focusing on the different forms of public private interplay (PPI) in New Zealand, the analysis evaluated the risk allocation within the partners involved in the UFB initiative by characterizing different forms of risks. In this context, PPI are considered as alternative means of generating value for private and public stakeholders by lowering risk and reducing uncertainty for private investment.

In the following, the theoretical foundations of public private interplay are discussed (section one). Afterwards, the emergence of public private interplay in the broadband sector is put in the context of the discussion on next generation networks in New Zealand and in Europe (section two). Then, the evolution and the structure of the broadband sector in New Zealand is compared to

\footnotetext{
${ }^{1}$ For the list of selected high income OECD countries see Table 1 and Table 2.
} 
development in Europe over the past ten years. Finally, the UFB initiative and the different forms of PPIs are discussed. The paper concludes with a discussion of the main findings.

\section{The incentive for private partners in public private interplay in broadband development: Theoretical perspectives}

\subsection{The national regulatory and legislative framework for public intervention in broadband markets}

In the growing literature on the role of public intervention in the development of broadband, the main arguments have been related to public goods properties of broadband and the effects of competition on broadband (Picot \& Wernick, 2007). If public sector entities intend to facilitate broadband deployment, they face the delicate task of putting forward legitimate reasons for intervention ranging from basic infrastructure and market failure arguments to opportunistic rationales (Lehr, Sirbu, \& Gillett, 2006; Sadowski, Nucciarelli, \& de Rooij, 2009). A central argument in the political discussions has been whether (or not) broadband can be considered as a public good characterized by non-excludability (i.e. no one can be excluded from consumption) and non-rivalry (i.e. consumption by an individual does not reduce the availability of the good to others) (Picot \& Wernick, 2007). Based on the public goods properties of broadband, the discussion would focus on the public funding available for broadband diffusion and the different ways of stimulating demand. Competition-related arguments, in contrast, have been put forward to discuss more efficient ways of improving the terms and the design of market regulation, in particular with respect to facilitating inter- and intra-platform competition in broadband markets.

As a result of balancing public-goods related and competition-related arguments, national government in the OECD countries have developed a variety of regulatory models ranging from "distinctly deregulatory" (observable in the United States); to an "interventionist approach" (Japan and Korea) and a "third or middle way" with a focus on regulatory intervention using competition analysis which should limit the impact of industrial policy (European Union) (Huigen \& Cave, 2008). In New Zealand, the role of government has recently changed from a more deregulatory approach towards a more interventionist approach in which the government becomes involved in the precise specification of the network technology, network implementation and the selection of firms 
responsible for network rollout. The regulatory and legislative framework in the European Union and New Zealand has provided important pre-conditions for the different types of public intervention available and involvement of private companies in broadband development.

Since the 1990s, different types of public intervention in broadband markets have emerged ranging from public utility models in which a vertically integrated public sector entity supplies services to market based provisioning of broadband services in which arms-length transactions have governed the interaction between different public and private partners. In this context, public private interplay (PPI) is considered as an alternative means of implementing broadband networks, combining public objectives and private interests whilst at the same time complying with the national (and supranational) regulatory and legislative framework. In Europe, PPI has been considered in the context of governmental efforts to comply with the European regulatory and legislative framework while balancing issues of competition-related and public-goods aspects of broadband deployment (Sadowski, et al., 2009). In contrast to their increasing importance in Europe (Deloitte, 2006), public private partnerships have hardly operated at all in New Zealand until very recently (Jock, 2010; NIU, 2011). This resistance against these partnerships can be traced back (Owles, 2008) to a paper for the Treasury on Financing Infrastructure Projects which found "little empirical evidence about costs and benefits of public private partnerships" (Katz, 2006). As a result, the New Zealand market for PPI has been considered as "developing" (Deloitte, 2006; NIU, 2011). Recently the discussion has shifted to the role of PPI in providing incentives to private partners to participate in these initiatives in order to facilitate broadband rollout (Falch \& Henten, 2010; Jock, 2010; Nucciarelli, Sadowski, \& Achard, 2010). In this way, the incentive structure of PPI with respect to risk and task allocation has to be examined.

\subsection{The economic foundations of public private interplay}

For a long time, public private partnerships have been considered as a way to outsource public services due to budget constraints and as the "lesser evil" in situations in which traditional forms of government provision of these services seem less efficient compared to pure market provision of these services. During this period, most research has focused on describing best practice for public private partnerships (Hodge, Greve, \& Boardman, 2010). More recently research has focused on the different tasks, which can be better be allocated to either a public or a private party in public private partnerships because they are better equipped to plan, execute or manage these tasks (Bettignies \& Ross, 2004). As a result, economists has been on the effects of public private partnerships on 
competition, the asymmetric risk allocation in public private partnerships, the nature of the relationship-specific assets and the incentive structures for the parties involved (Bettignies \& Ross, 2004).

The growing literature on public private partnerships has more reluctantly (Bettignies \& Ross, 2004, 2011) provided an economic foundation for these partnerships by concentrating on contract and ownership issues (Hart, 2003), risk allocation (Allen \& Lueck, 1999) and performance (Chong, Huet, Saussier, \& Steiner, 2006). Early work by Williamson on franchise bidding of CATV (1976) provided a robust micro-economic foundation for analysing the impact of different uncertainties on the choice for different government mechanisms. Rooted in this tradition an increasing number of empirical studies have used transaction costs economics as a theoretical framework (Shelanski \& Klein, 1999). More recently, a variety of other theoretical economic traditions have focused on the institutional (Koppenjan \& Enserink, 2009) and structural factors (Link, 2006; Link \& Scott, 2001) of public private partnerships. As contracting problems have been extensively studied in a static context, dynamic approaches towards risk allocation in areas like research and development (R\&D) in public private partnerships have rather been scarce (Link, 2006; Link \& Scott, 2001). Recently the role of these partnerships on the allocation of incentives for private parties to foster investment has become a new line of research in the area of broadband diffusion (Falch \& Henten, 2008; Howell, 2010; Sadowski, Nucciarelli, \& de Rooij, 2009). In this context, public private interplay (PPI) is defined as an alternative means for public and private stakeholders to generate value by lowering risk and reducing uncertainty for private investment (Gomez-Barroso \& Feijóo, 2010; Nucciarelli, et al., 2010). In the interplay between public and private stakeholders, two extreme models can be distinguished: the public utility model (i.e. public institutions are responsible for retail access) and the market-based model (i.e. private companies provide retail access). In the first model, public funding of the network is the only available financial source. The risk of the entire project has to be taken by public institutions, which deploy the network to perceive targets of public interests (e.g. bridging digital divide, providing e-government services). In the second model, public funding is usually accompanied by private funding. The interplay of public and private actors usually takes the form of a public-private partnership (PPP) in which mutual financial contribution is crucial (Nucciarelli, et al., 2010).

In industries characterized by very large fixed and sunk costs like telecommunications, PPPs have been used to foster investment in segments in which competitive firms are unable or unwilling to invest. For example, private investors have been reluctant to invest in the passive part of a new 
fiber-based network as these investments have not only a very long payback period but they are also difficult to recover for regulated firms (OECD, 2008a). In the Netherlands, for example, a number of fiber investment initiatives have taken the form of a PPP in which public and private parties have taken up different responsibilities for risks in the initial phase of a PPP (Sadowski, et al., 2009). For New Zealand, PPPs replicating a vertically integrated production chain using a mixture of contracts and relationship-specific investments seem to have worked rather well to foster long-term investment (Howell, 2010).

As the responsibility for service provision is a public task, its management can be either public or private. Local authorities may decide to transfer some of their decision and revenue rights to an external operator. At one extreme the public authority may choose direct public provision (e.g. state owned enterprises) and itself as undertaking all operations and investments needed for the provision of the service. Alternatively, the local public authority may choose to involve an outside firm in the operation of the service choosing a contract in which it pays and external operator a fixed fee (e.g. management or service contract) or an intermediary management contract (e.g. concession) that is similar to a management or service contract except that a small part of the operators revenues depend on its performance. These contracts provide few incentives to reduce costs and transfer some risks and decision rights to private operators.

The risks should be allocated within a PPP in way that the party which can best bear the risk should also take up responsibility. This responsibility is mostly defined in the contractual agreements between the public and the private party. If the risks are wrongly allocated, the incentive structure of the PPP is insufficient for the parties involved and the output of the PPP in terms of quantity and quality of service can be negatively affected. Therefore the transfer of the risks to a party which is not the most appropriate to bear the risk can result in inefficiencies of the PPP.

Across different infrastructure industries, there are several categories of risk relevant for the supply of public services. On the basis of previous studies (Hodge \& Greve, 2007; lossa \& Velez, 2007; Muselaers \& Stil, 2010; OECD, 2008b), we made a distinction between the following risks: Statutory and Policy risks; Design, construction, time schedule, and operation risk; Technical risk; Demand and revenue risk; Legislative/Regulatory risk; Financial risk and residual value risk. Within contracts, allocation of risk is achieved via different payment schemes as well as specific clauses that define the liabilities of different parties if specified circumstances should arise. 


\section{The UFB initiative in the light of the European Broadband Guidelines: Theoretical Perspectives and Policies}

\subsection{Commonalities and Differences Broadband Policies in Europe and New Zealand}

\subsubsection{The Broadband Guidelines (2009) of the European Commission}

In Europe, case law has governed the implementation of municipal NGA networks until September 2009 when the European Commission published the Broadband Guidelines (in the following Guidelines). Since 2003, 47 cases on municipal broadband development have been investigated by the European Commission. The experience gained during these investigations has been utilized in the Guidelines which have been implemented after finishing the consultation process in 2009 . The Guidelines have become an integral part of the "Digital Agenda for Europe" which specifies in much greater detail "the key enabling role that the use of Information and Communication Technologies (ICT) will have to play if Europe wants to succeed in its ambitions for 2020" (CEU, 2010). Since 2009, 54 new investigations have been started, with four still underway (European Commission Competition Directorate-General, 2012).

In the 2009 Guidelines, after discussing the importance of broadband for economic growth and recovery in Europe (Introduction) the European Commission (in the following Commission), specifies the rules applying for State aid regulations with respect to traditional broadband networks (Section 2) networks and with respect to Next Generation Access (NGA) networks (Section 3).

In Section 2, the CEU discusses the issue of State Aid and considers it as reasonable, in general, in rural and underserved areas, whereas it can distort competition in areas where broadband infrastructure already exists and competition takes place. In order to assess whether or not State Aid is appropriate a balancing test has to be undertaken involving the positive effects generated by an initiative related to the extent to which it incorporates "common interests" valued against its potential negative effects, related e.g. to "distortions of trade and competition" (section 2.3.1 of Guidelines). In the balancing test, the Commission defined specific criteria for the balancing test: if the objective of the common interests is well-defined, is a) State Aid still the most suitable instrument (or there are better instruments available; b) is there an incentive effect, i.e. "does State Aid change the behavior of undertakings" and c) is the State Aid measure still proportional (or is less public support more appropriate) (para. 35). 
In order to specify different types of public intervention, the CEU introduces the market economy investor principle (MEIP) as a way for a public party to invest in broadband without interfering with State Aid. In this case, the roll-out of broadband can be supported by a public intervention based on equity participation or by direct or indirect capital injections at market conditions into the undertaking company (para. 17). In addition, the Guidelines characterize as a fundamental case of absence of State Aid the principle of "Service of General Economic Interest"(SGEI). In this case, public compensation payments can be made as they do not constitute State aid. The principle of SGEI requires that a number of criteria are fulfilled: (1) the obligations for the party formally entrusted with public funding based on SGEI should be clearly defined, (2) to avoid an economic advantage to this party, the parameters for the compensation should be objective and transparent, (3) the compensation paid to this party should cover all actual costs for the SGEI plus a reasonable profit, and (4) this cost of this party should be compared to a typical and well-run company (para. 22).

The Commission defined different migration paths depending on the specific area addressed ("white", "black" and "grey" areas) depending on the prevalence of other broadband providers and the (non-)existence of competition in the area. For the evaluation of proposals in particular for grey areas, the Guidelines provide a number of criteria like detailed mapping and coverage analysis, tendering, most economically advantageous offer, technology neutrality, the use of existing infrastructure, conditions of wholesale access and benchmarking prices. As for the traditional broadband, public intervention in "white areas" is considered to be "in line" with State Aid regulations (section 2.3.2.1). In "black areas", there is no need for State intervention as there is "no market failure" (section 2.3.2.2), for "grey areas" a more detailed assessment is necessary (section 2.3.2.3). Furthermore, the Guidelines specify different options for public intervention in the case of NGA networks. In "white areas", public intervention is generally "supported" (section 3.4.1). In "grey areas", a "more detailed assessment" is required by looking e.g. at prices, services provided and demand for new services in the area (section 3.4.2). In "black areas" there again is "no need for State intervention" (section 3.4.3) just in cases where there is insufficient investment of existing market parties thus giving municipalities the opportunity to offer financial support (Articles 77 and 78).

Separation have not been a part of the Guidelines, as there is just limited experience in Europe with respect to separation issues (e.g. in the United Kingdom and Italy (Nucciarelli \& Sadowski, 2010)) and NGA developments. 


\subsubsection{NGA networks and the UFB initiative in New Zealand}

In December 2008, the Commerce Commission of New Zealand initiated a discussion on the future of NGA networks with a discussion paper which included as important characteristics: a) that they should be aimed at long-term benefits of end users; b) preservation of incentives in particular in access networks; c) self-regulation of the industry should be preserved; d) regulation only be necessary to constrain market power and e) regulation should be scaled back if workable competition emerges. The document included a variety of technologies able to deliver NGA ranging from fiber technologies (e.g. FTTx or PON technologies) to coax-based cable, mobile and fixed wireless networks (Commerce Commission New Zealand, 2008). As part of the discussion, the Commerce Commission of New Zealand organized in May 2009 a conference called "Next Generation Networks: Strategic Issues and Key Themes" to identify consensus and divergence of market parties with respect to NGA definitions, examine the strategic effects of technological change on market structure and competition in broadband markets as well as identify areas in which regulation is warranted (Commerce Commission New Zealand, 2009). Currently a broad definition of NGA is used by the Commerce Commission of New Zealand which refers "changes to telecommunication core and access networks to provide for modern day voice, data and media services" (Commerce Commission New Zealand, 2012b). There are no further distinctions between basic broadband and NGA technologies.

On 21 October 2009 the New Zealand Government issued an invitation to participate potential partners to submit proposals on how they would co-invest with the Government to achieve its UltraFast Broadband objective (the so-called UFB Initiative). The UFB Initiative specified as objective "to accelerate the roll-out of Ultra-Fast Broadband to $75 \%$ of the New Zealand population over ten years, concentrating in the first six years on priority broadband users such as businesses, schools and health services, plus greenfield developments and certain tranches of residential areas" (Crown Fibre Holdings Limited, 2011). It has been emphasized that very high speed is important rather than universal coverage (Jock, 2010).

With respect to the UFB initiative, the specifications of the technologies used can be found in the different Network Infrastructure Project Agreements between LFCs and CFH as well as between Chorus and CFH. The criterion used to guarantee technology neutrality as along as both PON and Point-to-Point architectures are used for UFB and the deployment meets agreed standards. For Northpower, for example, the technology deployed refers to "any electronic and/or optical equipment installed in the LFC's cabinet, Central Office and/or POI, and any active electronic 
equipment installed in the Central Offices or cabinets, in the Coverage Area, required to provide the Specified Layer 2 Services". (Northpower \& Crown Fibre Holdings Limited, 2011). For Chorus, the definition is related to "any fibre network infrastructure in the Coverage Area which is deployed independently of any End-User Specific Infrastructure and which is not located on Premises, including any of the following within the Coverage Area" (Telecom Corporation of New Zealand Limited \& Crown Fibre Holdings Limited, 2011). In other words, LFCs and Chorus both deploy wholesale access based on a variety of fiber technologies.

The coverage analysis has been included in the different Network Infrastructure Project Agreements of the LFCs and Chorus and actually meant geographical coverage. Further distinctions with respect to the pre-existence of other broadband providers and the existence of market competition have not been undertaken as fibre broadband access does not have significant market relevance on a national scale in New Zealand (Neumann, Schäfer, Doose, \& Elixmann, 2011). However, there is an existing provider of fiber access in the Wellington area (CityLink) which is not part of the UFB initiative (Howell, 2010) which will encounter problems with respect to market competition in the near future.

In changing the Telecommunications Act of 2001, the Government of New Zealand passed in December 2006 a number of Amendments aimed at achieve Operational Separation of Telecom New Zealand (Howell, Meade, \& O'Connor, 2010). The purpose of these changes (see Part 2A of the Act) was: the promotion of competition, the achievement of more transparency, non-discrimination and equivalence of supply in relation to certain services, and facilitate efficient investment in telecommunications services. In May 2011, a separate agreement between CFH and Telecom Corporation of New Zealand (Telecom NZ) came into existence which required Telecom NZ to structurally separate its wholesale and retail activities. This separation was undertaken by November 2011 leaving Telecom NZ with retail (and mobile) operations and assigning wholesale activities to Chorus as a facility based provider.

\subsubsection{Commonalities and Differences}

Similar to the European Commission, the government in New Zealand discovered in the 2008/9 the recognized the value of NGA networks for economic growth, in general, and for development of the broadband sector, in particular. Despite a broad discussion on the definition of NGA networks which took place in Europe and in New Zealand, different definitions are used in both countries to 
characterize NGA networks. In the European context, clear preference is given by defining NGA networks as wired networks (and exclude wireless and satellite but also copper networks). Furthermore, the European Commission has defined different types of public intervention referring to public investment similar to market investor (MEIP principle) or based on public and social objective (SGEI principle). Furthermore, the Commission makes further distinctions between traditional broadband and next generation access networks which allow for a variety of migration paths in different coverage areas. "White areas" (with no pre-existing broadband or NGA networks) are mostly eligible for State Aid, for "grey areas" (with broadband providers and even NGA networks) a detailed assessment is necessary. In "black areas' (with more than one NGA providers) no public intervention is necessary, but there are exceptions. In the case of New Zealand, the UFB initiative is changing the broadband landscape very fast as most "coverage areas" do not have any NGA infrastructure, with the exception of Wellington. There has been limited experience with separation in Europe and its effects of NGA rollout. In the New Zealand case, this experience is rather recent. However, it can be assumed that the relevant question with respect to NGA development in New Zealand is not so much related to the issues of separation, but challenges created by infrastructure competition in broadband markets and the consequence of policy decisions emerging from the UFB implementation. 


\begin{tabular}{|c|c|c|c|}
\hline Criteria & \multicolumn{2}{|l|}{ European Guidelines (2009) } & UFB initiative \\
\hline Definition of NGA & \multicolumn{2}{|c|}{$\begin{array}{l}\text { "wired access networks which consist wholly or in part of optical } \\
\text { elements and which are capable of delivering broadband access } \\
\text { services with enhanced characteristics (such as higher throughput) as } \\
\text { compared to those provided over existing copper networks" }\end{array}$} & $\begin{array}{l}\text { "broad term to describe changes to telecommunication core and access } \\
\text { networks to provide for modern day voice, data and media services."(1) }\end{array}$ \\
\hline NGA technologies & \multicolumn{2}{|c|}{$\begin{array}{l}\text { "Mainly fibre-based or advanced upgraded cable networks that are } \\
\text { intended to replace in whole or to a large extent the existing copper- } \\
\text { based broadband networks or current cable networks." Including VDSL } \\
\text { or Docsis } 3.0 \text { cable networks }\end{array}$} & $\begin{array}{l}\text { PON and Point-to-Point architectures are used for UFB as long as the } \\
\text { deployment meets standards (specified in Network Infrastructure Project } \\
\text { Agreements) }\end{array}$ \\
\hline $\begin{array}{l}\text { Types of public } \\
\text { intervention }\end{array}$ & \multicolumn{2}{|c|}{$\begin{array}{l}\text { MEIP: Equity participation at market conditions (para. 17). } \\
\text { SGEI: Public compensation based social and economic objectives }\end{array}$} & $\begin{array}{l}\text { Different forms of public private partnerships with LFCs and CFH as well as } \\
\text { Chorus and CFH }\end{array}$ \\
\hline Migration paths & \multicolumn{2}{|c|}{ White areas, black areas and grey areas } & $\begin{array}{l}33 \text { geographic areas ("Candidate Coverage Areas"), areas not further } \\
\text { specified }\end{array}$ \\
\hline Criteria for Migration & Broadband Networks & NGA networks & Ultrafast Broadband \\
\hline White areas & $\begin{array}{l}\text { No plans of private investor for } 3 \\
\text { years ("in line") }\end{array}$ & $\begin{array}{l}\text { Broadband not sufficient to satisfy } \\
\text { needs, no less distorted means } \\
\text { ("support") }\end{array}$ & \multirow{3}{*}{$\begin{array}{l}\text { "LFC partnering model is intended to reduce the overall cost of the } \\
\text { Network build and avoid expensive duplication of copper and fibre } \\
\text { infrastructure in relevant coverage areas which will mean more efficient } \\
\text { use of capital and greater returns for the Company and LFC participants" } \\
\text { (Telecom Corporation of New Zealand Limited \& Crown Fibre Holdings } \\
\text { Limited, 2011) }\end{array}$} \\
\hline Black areas & $\begin{array}{l}\text { At least two broadband providers } \\
\text { ("no market failure") }\end{array}$ & $\begin{array}{l}\text { More than one NGA ("no need"), } \\
\text { but if no upgrading plans of } \\
\text { existing parties ( } 3 \text { years) }\end{array}$ & \\
\hline Grey areas & $\begin{array}{l}\text { "De facto monopoly" ("detailed } \\
\text { assessment") }\end{array}$ & $\begin{array}{l}\text { NGA already deployed of planned } \\
\text { ("detailed assessment") }\end{array}$ & \\
\hline Separation & \multicolumn{2}{|l|}{ Not specified } & $\begin{array}{l}\text { Separation leading to Telecom NZ (retail (and mobile) operations and } \\
\text { assigning wholesale activities) and Chorus (facility based provider) }\end{array}$ \\
\hline
\end{tabular}

Sources: (Neumann, et al., 2011) and own investigation (1) website Commerce Commission New Zealand http://www.comcom.govt.nz/next-generationnetworks-2/

Table 1: The UFB initiative in the light of the European Broadband Guidelines (2009) 


\section{The Development of the Broadband Market and the UFB Initiative in New Zealand}

\subsection{The Development of the New Zealand Broadband Market}

\section{Market Size and Development}

Similar to other OECD countries, the New Zealand broadband market has rapidly grown since 2005 as the number of fixed connections are still (but slowly) increasing since 2008 (see Figure 1). The compounded average growth rate (CAGR) of the fixed network of New Zealand was between 2008 and 20110.02 percent compared to a close to zero growth in the previous period $2005-2008$. During the period 2002 - 2005 subscriptions to the fixed network were decreasing by 0.02 percent leading in total decrease in fixed connections of about 49.000 between the years 2011 and 2000 . This has also let to a decline in the penetration rate of the fixed network from 47.46 (2000) to 42.59 (2011). Interestingly the rank of New Zealand among other OECD countries changed very little from 23 (2000) to 21 (2011) (see Appendix 1). In most European countries, there has been a stronger decline in the fixed market compared to New Zealand.

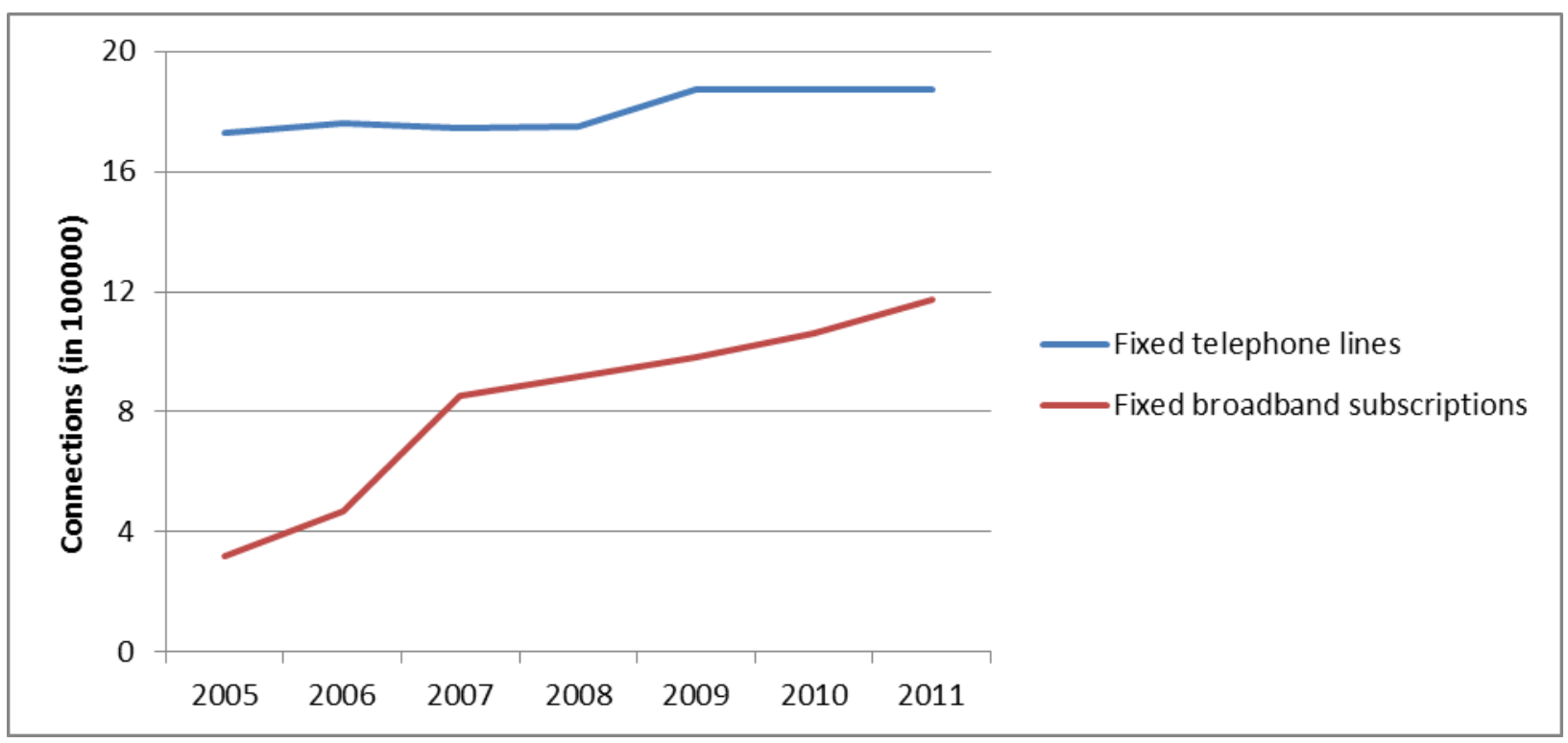

(Data: OECD/ITU 2012)

Figure 1: Fixed line telephone lines and broadband connections in New Zealand

With respect to number of fixed connections, the market in New Zealand has been similar to the markets in countries like Denmark, Norway and Sweden which have experienced a steeper decline in fixed connections since 2005 and in particular since 2008 (see Appendix 1). 
Telecom New Zealand is operating a nationwide ubiquitous fixed line network which supplied the majority of retail and wholesale fixed line services until its demerger in November 2011. After the demerger, Chorus owns the access part of the network and Telecom New Zealand maintains much of the core network providing backhaul between exchanges and other points of interconnection (Commerce Commission New Zealand, 2012a). As the total fixed line retail revenues have slowly been decreasing from 2.99 billion NZ\$ (2005) to 2.77 billion NZ\$ (2011), the share of Telecom New Zealand of the fixed retail revenues has fallen from 80 percent in 2005 to 67 percent in 2011 (Commerce Commission New Zealand, 2012a).

\section{Broadband Development}

Broadband development in New Zealand has been remarkable since 1002. In terms of broadband density, New Zealand moved from 0.12 broadband connections per 100 subscribers in $2002\left(22^{\text {nd }}\right.$ place) to 25.78 broadband connections per 100 subscribers in 2011 ( $19^{\text {th }}$ place). However, the growth has been well below the OECD average. Between 2002 and 2005, broadband connections in New Zealand were growing by 0.4 percent (OECD average: 0.56 ), growth decreased between 2005 and 2008 to just 0.02 percent (OECD average: 0.05 ) and slightly increased during the period 2008 and 2011 to 0.04 percent (OECD average 0.05 ). However, this growth was well below the OECD average during the period 2002 to 2011. Between 2011 and 2012, growth of broadband subscriptions in New Zealand (0.04) has just slightly higher compared to the OECD average (0.003) (see Appendix 2). In terms of broadband density, New Zealand has been similar to countries like Austria or Slovenia.

Interestingly, the growth of the broadband network in New Zealand has been fostered by just moderate private investment. In 2008/09, investment in the industry has been NZ\$1.69 and has dropped back in subsequent years to $\$ 1.24$ billion in 2010/11. However, decline in investment has largely been driven by Telecom New Zealand's extraordinary investment due to operational separation and its FFTN commitment to upgrade 3,600 roadside cabinets. Most investment in tangible infrastructure, in contrast, has remained relatively steady which has been different compared to other OECD countries were this type of investment has been weakened in the face of national crisis (Commerce Commission New Zealand, 2012a).

\section{Extent of Intermodal Competition}

Intermodal competition in broadband has been weak in New Zealand. As shown in Figure 2, development of broadband in New Zealand has since 2002 been driven by the growth of DSL connections with market shares around 90 percent. Cable broadband connections had just a small percentage of the broadband market in 2002 and this percentage has remained rather until 2012. Similarly the contribution of alternative technologies ("other" in Figure 2) such as wireless broadband, satellite broadband or fiber connection to total broadband has been low. 


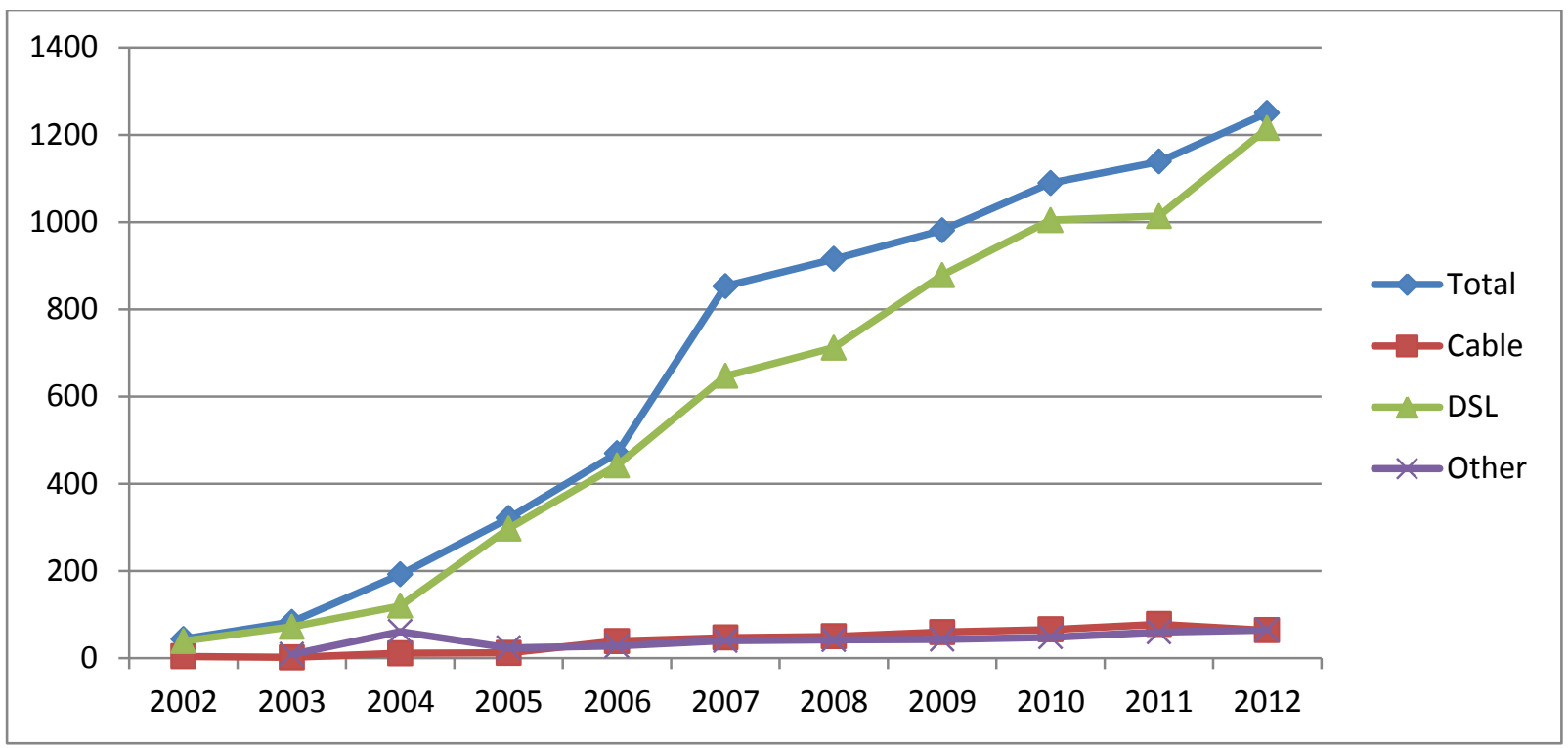

(Data: OECD/ITU 2012, estimates for 2012, for cable and DSL broadband connections for 2010 / 2011, others include $\mathrm{FttH}$, wireless broadband and satellite broadband connections)

Figure 2: Broadband connections in New Zealand per type since 2002

Telecom New Zealand has been the main provider of DSL connections in New Zealand. The company's wholesale broadband service is available nation-wide, in the DSL broadband market the company retails 57 percent of connections (Commerce Commission New Zealand, 2012a). The second-largest telecommunications company in New Zealand, TelstraClear (a wholly owned subsidiary of Telstra Corporation, Australia), is providing cable service with a very limited coverage (areas of the Wellington region and Christchurch). The company uses local loop unbundling and resale to provide fixed line retail services in many other locations around New Zealand including Auckland, Hamilton, Tauranga and Dunedin. Unbundled copper loop line(s) (UCLL) are currently widely available (at 106 exchanges as at the 31 March 2011, serving around (65\% of total lines).

In June 2011, the market share of the different types of technology to total broadband was about 89 percent DSL and just around 8 percent cable connections (see Figure 2).

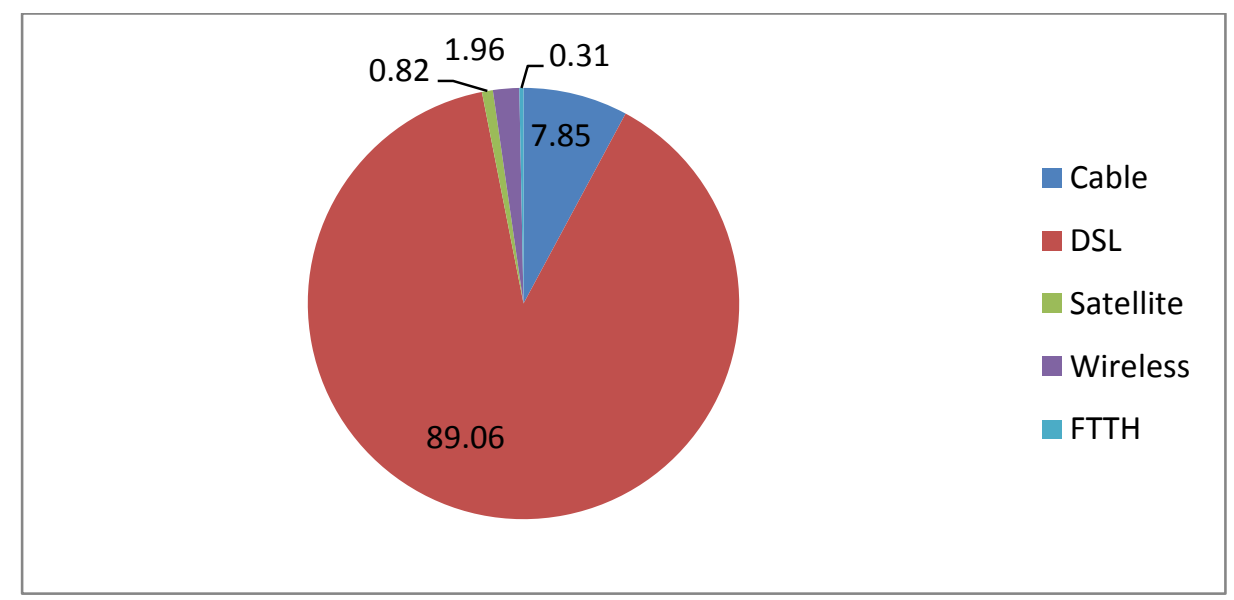

(Data: OECD/ITU 2012, estimates for cable and DSL broadband connections)

Figure 2: Market share per technology (June 2011) 
In addition, there are five smaller companies with core networks which are using local loop unbundling to provide voice and broadband services (Vodafone, Orcon, Slingshot/CallPlus and Compass). Recently unbundled local loops are also being used in smaller cities and towns like Invercargill, Masterton and Feilding to provide services.

Furthermore, there are a number of competing retailers like WorldxChange and TrustPower Kinect which are reselling services of Telecom New Zealand using different bundling strategies based on voice and broadband offerings. These strategies are aimed at increasing the number of consumers purchasing already fixed line services from them (Commerce Commission New Zealand, 2012a). In contrast to the average in European Union (EU27), the share of DSL connections on total broadband has been rather high. In countries like the United Kingdom and the Netherlands, the market share of of DSL on total broadband has been lower (around 60 percent in the Netherlands and 80 percent in the United Kingdom) (see Figure 3).

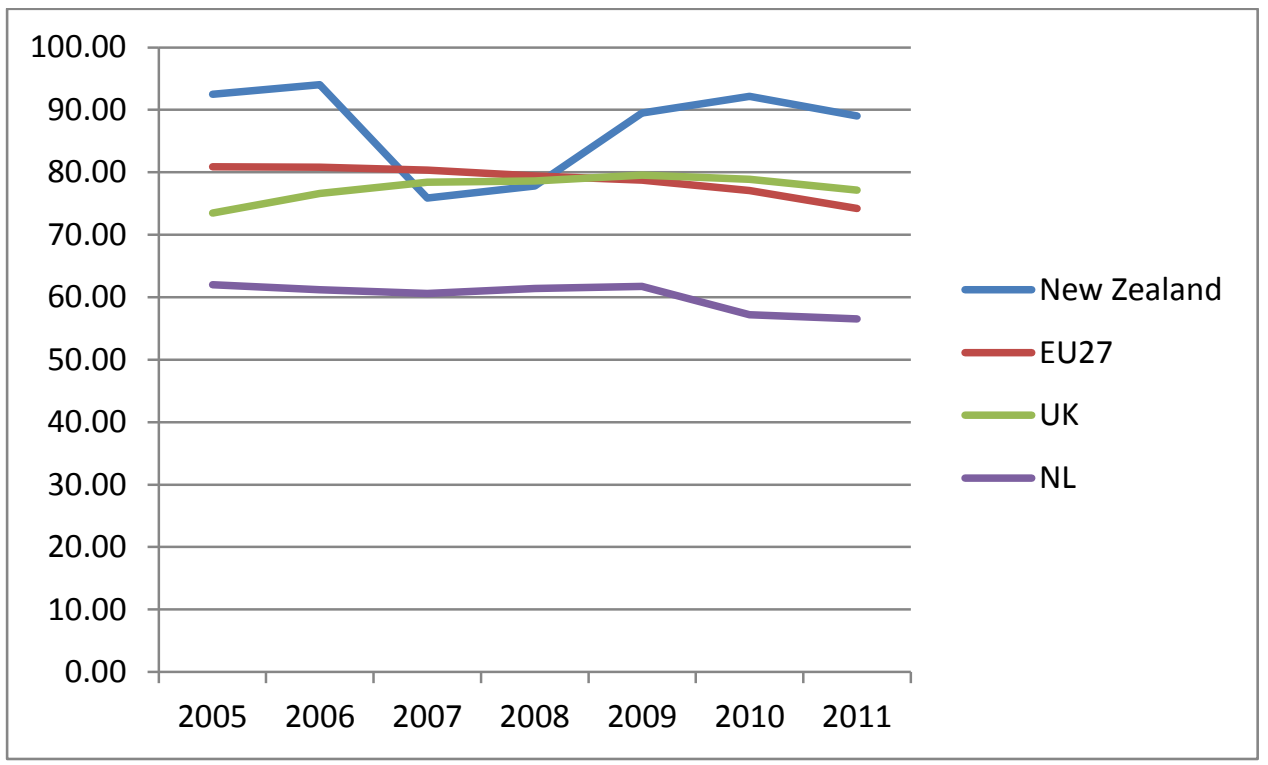

(Data: European Commission, 2012; Commerce Commission NZ, 2012)

Figure 3: Market share of DSL on broadband

However, due to unbundling concentration in markets for fixed line broadband services measured using the HHI index has been decreasing from 5725 in 2005 to 4125 in 2009 and below 4000 in 2011 (Commerce Commission New Zealand, 2012a).

\section{Regulatory Development effecting broadband development in New Zealand}

In contrast to the ("third" way) European approach, the 'light-handed' regulatory approach prevailing in New Zealand until 2001 changed after a new government took charge, with the implementation of the Telecommunications Act 2001 and the establishment of an industry-specific regulatory body: the Office of the Telecommunications Commissioner. The 2001 Act replaced the 1987 Telecommunications Act with the aim to bring greater certainty, investment, competition and 
consumer benefits to the telecommunications sector. The main purpose of the Act was "to regulate the supply of telecommunications services" in New Zealand by defining a set of designated or specified services which included broadband services. After the Minister accepted the Commission recommendation in 2004 not to unbundle local loop, a 'Stocktake' of the telecommunications industry by the Ministry of Economic Development in December 2005 changed this decision. The primary focus of the 'Stocktake' was to consider "the broadband market and our broadband performance as a factor in economic performance" (MED, 2006). The recommendations of the Commission let to a reform of the Telecommunications Act. In December 2006, the Telecommunications Amendment Act (No 2) was passed which included major changes with respect to the Commission's telecommunications regulatory functions. These changes included: the introduction of unbundled copper, subloop regulation and removal of speed constraint on bitstream service; backhaul service regulation. Furthermore, these amendments included the provisions for the operational and accounting separation of Telecom New Zealand (separation in 3 units (Access (Chorus) Wholesale \& Retail)). In 2007, the Commission took a decision on the unbundled local loop and bitstream service decision.

In December 2011, Chorus announced that the rollout of its FTTN network was officially finished. The rollout of the FTTN network was part of the operational separation undertakings agreed upon between Telecom New Zealand and the New Zealand government already in 2008. The agreement included as requirements that the network should deliver a minimum of $10 \mathrm{Mbps}$ by providing coverage to $80 \%$ of New Zealand. As a result, a total of 3,600 roadside cabinets were upgraded by Chorus (Commerce Commission New Zealand, 2012a).

In 2009, the New Zealand government established with the Crown Fibre Holdings Limited (CFH) a limited company to manage the $\$ 1.5$ billion investment in Ultra-Fast Broadband infrastructure. CFH has been established which received 33 proposals from 18 interested parties by January 2010 to participate in this initiative. After reviewing the proposals of these parties, CFH asked for revisions and refinements of the different proposal which were received by August 2010. In September 2010, the CFH published a shortlist of 14 parties ( 3 shortlisted and "elected for" negotiations and 11 (just) shortlisted) which intended to cover all 33 UFB Candidate Areas. In December 2010, agreements between CFH and Northpower, Ultra Fast Fibre Limited and Enable (the so-called "Local Fiber Companies or LFCs") were drawn up .

On 24 May 2011, the CFH announced that it had completed selection process for UFB partners in signing contracts with Telecom Corporation of New Zealand and Christchurch City Holdings. Earlier contracts had been signed with WEL Networks and Northpower in December 2010. Rollout within the UFB framework started in December 2010 (Crown Fibre Holdings Limited, 2011a). 


\begin{tabular}{|c|c|c|c|}
\hline 2010 & \multicolumn{3}{|c|}{$\begin{array}{l}\text { UFB investment initiative \& Crown Fibre Holdings (CFH) (Statement of Intent) : Rollout UFB } \\
\text { to } 75 \% \text { New Zealanders over } 10 \text { years in first } 6 \text { years priority to business, schools, health service } \\
\text { plus greenfield developments and certain tranches of residential areas }\end{array}$} \\
\hline \multirow[t]{2}{*}{2009} & $\begin{array}{l}\text { Government's Broadband } \\
\text { Investment Initiative (GBII) }\end{array}$ & $\begin{array}{l}\text { Focus areas } \\
\text { Monitoring }\end{array}$ & IP interconnection, \\
\hline & \multicolumn{3}{|c|}{\begin{tabular}{l|l|l|} 
International Experience in NGN: Broadband rankings & \\
linked to Competition Issues (Open access)
\end{tabular}} \\
\hline 2008 & \multicolumn{3}{|c|}{ Operational Separation Undertakings agreed between Telecom and Government (31 March 2008) } \\
\hline 2007 & \multicolumn{3}{|c|}{ Unbundled local loop \& Bitstream service decision } \\
\hline 2006 & $\begin{array}{l}\text { Telecommunications } \\
\text { Act Reform }\end{array}$ & \multicolumn{2}{|c|}{$\begin{array}{l}\text { Commission's regulatory power enhanced: } \\
\text { - Telecom operationally separated in } 3 \text { units: Access } \\
\text { (Chorus) Wholesale \& Retail } \\
\text { - Introduction of unbundled copper \& subloop regulation } \\
\text { - } \quad \text { Removal of speed constraint on bitstream service; } \\
\text { backhaul service regulation }\end{array}$} \\
\hline 2005 & \multicolumn{3}{|c|}{$\begin{array}{l}\text { New Zealand behind OECD competitors in broadband } \\
\text { penetration. Telecom does not meet wholesale targets. }\end{array}$} \\
\hline 2004 & \multicolumn{3}{|c|}{$\begin{array}{l}\text { Minister accepted Commission recommendation not to unbundle local loop. Telecom agreed to } \\
\text { achieve wholesale targets. Bitstream service regulated with capped upstream speed } 128 \mathrm{kbps} \text {. }\end{array}$} \\
\hline 2001 & \multicolumn{3}{|l|}{ Telecommunications Act 2001} \\
\hline
\end{tabular}

(Adapted from (Funston, 2010) and own research)

Figure 4: Main governmental developments affecting broadband development in New Zealand since 2001

\subsection{The role of PPI in the UFB initiative in New Zealand}

\subsubsection{Start of UFB initiative in December 2010}

In the agreements with CFH and Chorus as well as with the LFCs and CFH, 33 priority areas were specified. With respect to these priority areas, Chorus was in charge of implementing the UFB initiative in close to 70 percent of the priority areas, followed by Enable (15.3 percent), WEL (13.7) and Northpower (1.6). Northpower is covering the Whangarei area. Enable limited takes up responsibility in Christchurch and Rangiora. Ultra Fast Fibre led by WEL Networks in Hamilton, Tauranga, Tokoroa, New Plymouth, Hawera and Wanganui. Chorus will be in charge in most other parts of the country (for an overview of these areas see Table 10). 


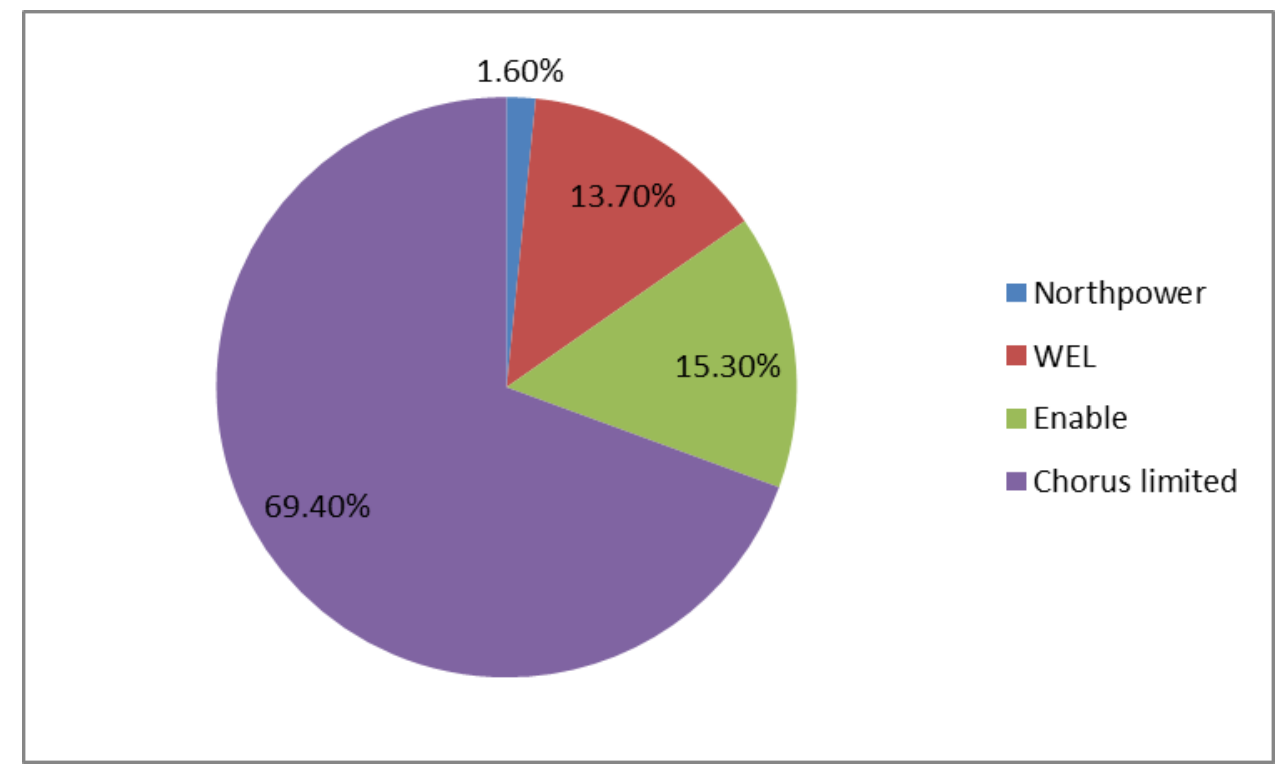

(Source: CFH 2012)

Figure 5: UFB coverage by three Local Fiber Companies and Chorus Limited

Northpower began with the UFB rollout already in December 2010 in Whangarei. The company expected to have connected 7300 premises by June 2012 (Northpower, 2012). In November 2011, Enable followed with rollout fiber in Christchurch with the objective to connect a population of more than 380,000 along with 7,000 businesses, some 1,000 medical centres and 170 schools. Over an eight year period the rollout should be completed. Government investment via CFH in Enable includes NZ \$200 million (Commerce Commission New Zealand, 2012a). Ultrafast Fiber began in April 2012 with the rollout of fiber in Plymouth and should provide fibre access to 32 schools by the end of June 2012 (Crown Fibre Holdings Limited, 2012b). Similarly, Chorus commenced with the UFB initiative in April 2012 in Timaru and expanded it in July to Invercargill, Nelson, Oamaru, Queenstown, Timaru and Whakatane (Crown Fibre Holdings Limited, 2012a).

In order to provide fiber based services to end customers, Chorus and the different Local Fibre Companies (in conjunction with CFH) engaged during 2011 in an industry consultation process with potential retail service providers (RSPs) at the Telecommunications Carriers' Forum (TCF) to specific commercial terms of the UFB. In August 2011, Chorus was the first to release its "Reference Offer" which included the General Terms (Wholesale Services Agreement), Service Descriptions, Service Level Terms, Operations Manuals, End User Terms and Price Lists. In November 2011, Northpower Fibre provided its specifications in the Reference Offer. Ultrafast Fibre Limited and Enable Networks followed with their Reference Offers in February 2012.

In February 2012, Chorus, Enable Networks, UltraFast Fiber and Northpower and other members of the Telecommunications Carrier Forum (TCF) wrote secretly to the Minister for Communications Amy Adams a letter called "CFH's Future Role" calling for CFH to be sidelined or scrapped. They argued that after $\mathrm{CFH}$ selected the coverage areas and set wholesale prices the "level of intervention and decision making powers by CFH inappropriately constrain the effective rollout of UFB". According to TCF, this inappropriate role of CFH was reflected, firstly, in its double status as partner in the rollout and at the same time as quasi-regulator; secondly, in its efforts to achieve national standardization and its involvement in the negotiating supply contracts and thirdly in its role to 
"drive uptake through awareness and other initiatives". Interestingly, the TCF already envisaged a situation in which "uptake is deemed to be too low in the near future". However, the forum's advice was that "involvement of CFH is not sought by retailers as they are confident that they can promote the broadband use without CFH assistance" (Telecommunications Carrier Forum, 2012).

According to the Communications and Information Technology Minister Amy Adams, by August 2012 the UFB project had already exceeded its one year-one rollout target by more than 6,000 premises, leading to an expansion of the fibre network to more than 76,000 premises across New Zealand. During the period June 2011 and June 2012, 76,311 premises have officially been passed by the UFB network (originally planned: 70,000 ), with some 28,435 premises passed during the fourth quarter of this first year of the UFB initiative. Furthermore, the Rural Broadband Initiative delivered over the first period faster broadband to 69,000 rural homes and businesses, leading to some 585 schools which now have fibre connections past the school gate. In addition, four hospital connections have been completed (Amy Adams, 2012). However, actual uptake is trailing a long way behind. At the end of the first year of the UFB initiative only 1,233 users had been connected to the UFB with 155 of these users connected in the most recent quarter (Communications Day, 2012). 


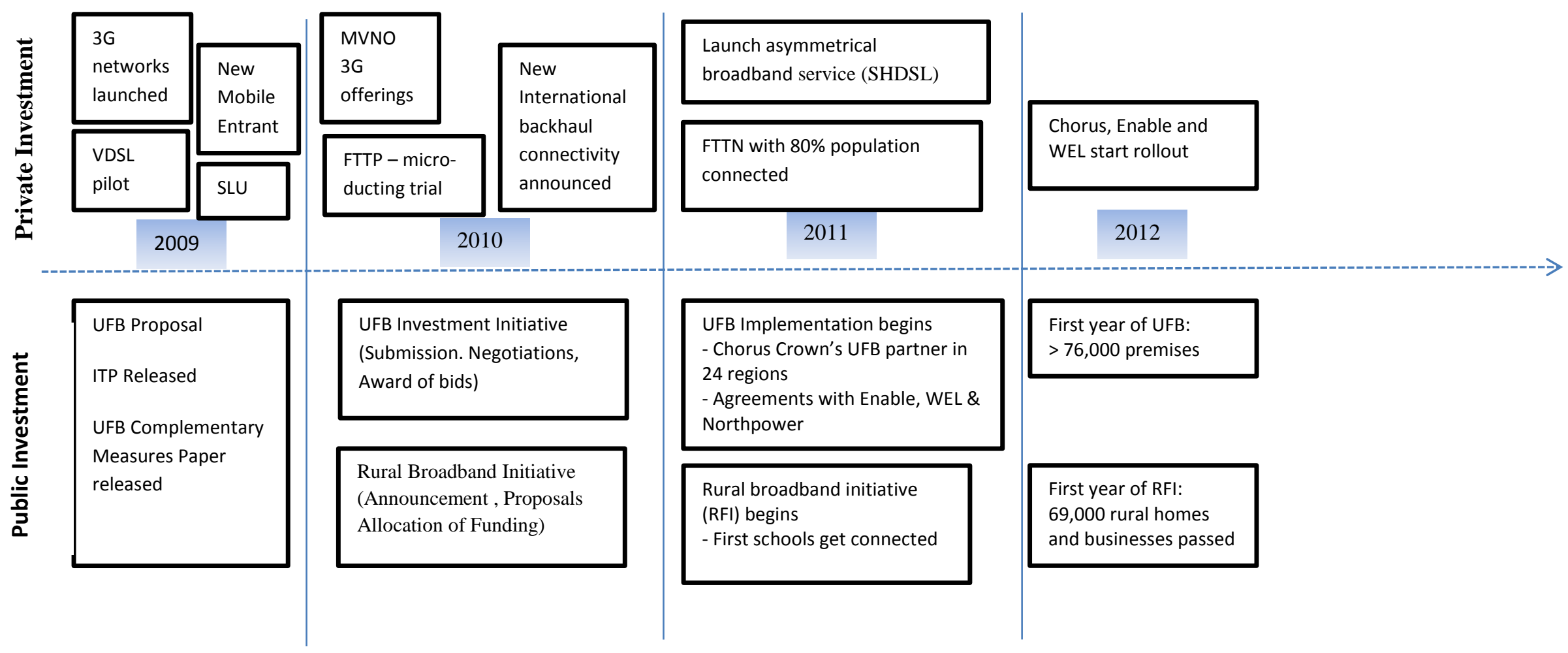

(Adapted from (Funston, 2010) and own research)

Figure 3: Timeline Private and Public Investment Initiatives in New Zealand since 2009 


\subsubsection{The role of PFI's in the UFB initiative}

In contrast to their increasing growth on a global scale (Deloitte, 2006), private-public partnerships (PPPs) have hardly operated at all in New Zealand until very recently (Jock, 2010; NIU, 2011). This resistance against PPPs has been traced back (Owles, 2008) to a paper for the Treasury on Financing Infrastructure Projects which found "little empirical evidence about costs and benefits of PPPs" (Katz, 2006). As a result, the New Zealand market for PPPs has been considered as "developing" (Deloitte, 2006; NIU, 2011). In order to facilitate a more mature market for PPPs in New Zealand, the National Infrastructure Unit (NIU) of the Treasury has published a strategy paper "Managing the Implications of Public Private Partnerships" in which it has laid out the rationales and the importance of providing (public) support to PPPs and has described two experiments with innovative PPPs in the area of education and prison (NIU, 2011). However, the vision document has been focused on the problems related to performance criteria and the management of the relationship between the different partners, to a lesser extent on the driving forces of public and private parties in entering into PPPs and the resulting choices for particular forms of PPPs.

With respect to the UFB initiative, the public private interplay between CFH and the four UFB companies (Chorus, UltraFast Fibre Ltd, Northpower and Enable) took very different and complex forms (Jock, 2010). With UltraFast Fibre Ltd, Northpower and Enable, CFH signed contracts leading to different governance forms compared to Chorus (came into force as a result of a demerger from Telecom New Zealand). Based on different contractual relationships, CFH has invested NZ\$929 million directly in Chorus with 50 percent being voting shares and 50 percent interest free loans (Flechter, 2011). The other three other companies formed a joint venture with CFH (see Figure 9).

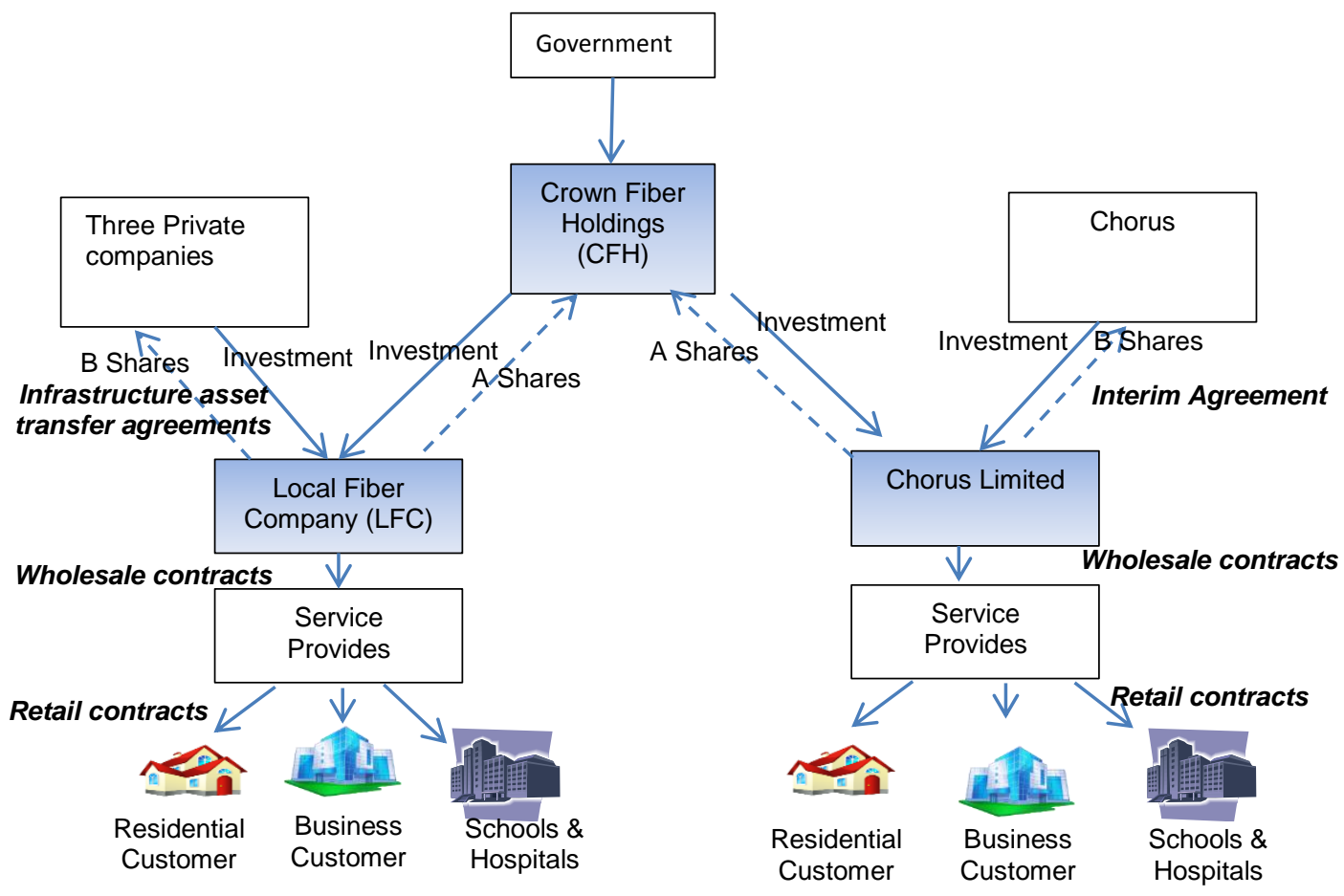

Figure 4: Contracting and Control of UFB investment 
The NZ Government supported the LFCs in deploying UFB initiative with NZ\$ 1.5 billion. It is expected that with further private investments the overall UFB scheme investments will be a total of around NZ\$ 3 billion. The different partners in the PFIs are CFH and different private firms (Northpower, UltraFastFibre Limited and Enable) as well as $\mathrm{CFH}$ and Chorus limited. These companies receive a concession for a period of 10 years. The three private firms invest in so-called three Local Fiber Companies ("LFCs"). CFH provides funding of the "communal" infrastructure i.e. voting $A$ shares are issued but no dividends are paid. The companies, in return, fund connection to end user costs leading to the issue of B non-voting $100 \%$ distribution shares. The different partner firms receive A shares when refunding CFH for "passing" costs on an end user basis. There is a Government Share, no voting rights or dividends, but the government has veto power. After the period of ten years, A and B shares converted into ordinary shares. However, the Government Share is not converted (Funston, 2010).

Interestingly, the agreements between the CFH and LFCs as well as CFH and Chorus were rather differed with respect to their ownership structure and the incentives for the companies involved (see Table 2). 


\begin{tabular}{|c|c|c|c|c|}
\hline & Chorus Limited & Northpower & Ultrafast Fibre Limited & Enable Networks Limited \\
\hline Industry & Telecom & Electricity Utility & Electricity Utility & Council owned \\
\hline Public investment & $\begin{array}{l}\text { CFH is investing in Chorus Limited } \\
\text { in form of debt and equity }\end{array}$ & \multicolumn{3}{|c|}{ Investment in Local Fiber Companies (LFCs) } \\
\hline Partner / Private Company & $\begin{array}{l}\text { Chorus New Zealand's largest } \\
\text { telecom utility company }\end{array}$ & $\begin{array}{l}\text { Electrical contracting business and } \\
\text { delivers fibre reticulation services } \\
\text { as well as owning a FTTP network } \\
\text { in the Whangarei region. }\end{array}$ & $\begin{array}{l}\text { Waikato Networks Limited has } \\
\text { one shareholder, WEL Energy } \\
\text { Trust, a community trust that } \\
\text { represents interests of local } \\
\text { community }\end{array}$ & Christchurch City Council \\
\hline Ownership of partner & Private & Trust owned & Council Owned & Council Owned \\
\hline $\begin{array}{l}\text { Number of coverage areas (in } \\
\% \text { ) }\end{array}$ & $24(69.4 \%)$ & $1(1.6 \%)$ & $6(13.7 \%)$ & $2(15.3 \%)$ \\
\hline Coverage areas & 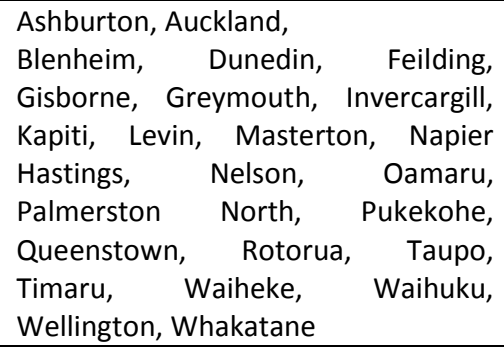 & Whangarei & $\begin{array}{l}\text { Hamilton (incl. Cambridge \& Te } \\
\text { Awamutu), Tauranga, Tokoroa, } \\
\text { New Plymouth, Hawera and } \\
\text { Wanganui }\end{array}$ & $\begin{array}{l}\text { Christchurch (including Rolleston) } \\
\text { and } \\
\text { Rangiora }\end{array}$ \\
\hline Retail Service providers & 66 RSPs & $\begin{array}{l}18 \text { RSPs (e.g. 2degrees, } \\
\text { Uber Group*, Vector Fibre and } \\
\text { Orcon*) }\end{array}$ & & $\begin{array}{l}21 \text { RSPs (e.g. 3T The Total Team, } \\
\text { Business IT and CallPlus) }\end{array}$ \\
\hline
\end{tabular}

Table 2: Different forms of PFI's in New Zealand: Partnering firms, Coverage and Retail Service Providers 
In the following the focus is on the contractual agreements with Chorus and CFH as well as with the joint venture agreements with the other three companies and CFH accounting for the different kind of risks discussed above.

\section{Statutory and political risks: Crown Fiber Holdings (CFH)}

The statutory and political risks have been specified by the CFH in the Statement of Intent 2011 2014 (Crown Fibre Holdings Limited, 2011a). CFH has tried to minimize the political risks by defining statutory rights in relying on a "statutory framework that applies to it, including (but not limited to) the Public Finance Act 1989, the Crown Entities Act 2004 and the Companies Act (Act) 1993." Furthermore, "Under the Act, the Board, each Director and each Shareholding Minister has the rights, powers, duties and obligations set out in the Act, except to the extent that they are negated or modified, in accordance with the Act, by CFH's constitution." In addition, "The (Ministry of Education) MED will be responsible (and CFH will not be responsible) for all regulatory and Government policy matters relating to the UFB Objective)" (Crown Fibre Holdings Limited, 2011a).

CFH will manage and monitor the Crown's co-investment with UFB partners in order to achieve the Government's UFB Objective. It takes responsibility for selection process of UFB partners, appropriate measures of co-investment have still to be developed. CFH is expected to be "eventually" commercially viable and provide "a commercial return on the Crown's investment, and operate as a successful business, when directed by the Shareholding Ministers and the Minister for Communications and Information Technology"(Crown Fibre Holdings Limited, 2011a).

In order to cover financial risks, CFH has been exempted by the Ministry of Finance from a number of sections of the Crowns Entities Act "due to the early stage of CFH's life cycle" related to statement of forecast service performance in the first financial year (Section $142(1)(b))$, classes of output the entity proposes to supply (Section 142 (2)) and statement of service performance in respect to the financial year to which it relates (Section $151(b)$ ).

\section{Risks and contractual agreements: Local Fiber Company (LFC)}

There are a number of contracts which are relevant for LFCs in the case of Northpower in particular the Network Infrastructure Project Agreement and Schedules which specifies, in detail, the design, construction, time schedule and operation risk (Whangarei Local Fibre Company Limited, Northpower Limited, \& Crown Fibre Holdings Limited, 2010b), the Network Infrastructure Asset Transfer Agreement which specified the financial risks (Whangarei Local Fibre Company Limited, Northpower Limited, \& Crown Fibre Holdings Limited, 2010a), the competitive risks in case of open 
access (Whangarei Local Fibre Company Limited, 2010). Similar contracts have been drawn up for the other two companies (UltraFast Fibre Ltd and Enable).

\section{Design, construction, time schedule, and operation risk}

Furthermore, as specified in the Network Infrastructure Project Agreement part Background sub F, Northpower would "own and control the Network in the Coverage Area, [and] would be solely responsible for the Design and Build and takes the risk of any cost and time overruns and any failure to comply with the Requirements." (Whangarei Local Fibre Company Limited, et al., 2010b). Furthermore, the company would take responsibility (and risks) for the contracts drawn up with "subcontractors (including for civil works) as required to build the New Infrastructure for delivery". In addition, the firm "will be responsible as primary obligor for all work carried out, and materials used or infrastructure provided, by any subcontractor" (Whangarei Local Fibre Company Limited, et al., 2010b). In the part Delivery of the agreement, further obligations for Northpower have been specified with respect to compliance with the network deployment plan, delays and damages (6.2) (Whangarei Local Fibre Company Limited, et al., 2010b). In addition the "risk in, and title to, each item of Equipment comprising the New Infrastructure will pass to the LFC on payment of the full Charges (or, if relevant, the Initial Cash Payment)." (6.3)

Interestingly a number of risks have already been specified within the contracts with LFCs with respect to statutory and political risks (mostly been taken by CFH and different ministries); Design, construction, time schedule, and operation risk (taken by the LFC). A number of other risks (like financial risks or residual value risks) have not sufficiently been specified yet. Further specifications will probably been done during the time the project progresses.

\section{Risks and contractual agreements: Chorus}

Contracts between Chorus and CFH have been initiated with respect to the Network Infrastructure Project Agreement which specifies, in detail, the design, construction, time schedule and operation risk (Telecom Corporation of New Zealand Limited \& Crown Fibre Holdings Limited, 2011) and the competitive risks based on open access (Chorus, 2011). In addition, there is an Interim Period Agreement which specifies the financial risks for Chorus (Crown Fibre Holdings Limited \& Telecom Corporation of New Zealand Limited, 2011).

In the opening of the Network Infrastructure Project Agreement ("Background"), the document specifies design, construction, time schedule and operation risks in the following way: Chorus "takes 
the risk of any cost and time overruns and any failure to comply with the Requirements. The Company will enter into such subcontracts (including for civil works) as required to build the New Infrastructure. The Company will be responsible as primary obligor for all work carried out, and materials used or infrastructure provided, by any Subcontractor or Group Company" (Telecom Corporation of New Zealand Limited \& Crown Fibre Holdings Limited, 2011). These risks are further defined in part 6 of the contract ("Performance").

The agreement acknowledges that there are some technical risks involved (part 7 "Improvements") with respect to "(a) improvements, developments and changes in technology, processes, practices, standards, architectures, interfaces and methodologies; (b) any changes in the Company's technology strategies and policies; and (c) opportunities with third parties" which might have a "significant effect on the Network (including Equipment and Software) or the O\&M Services (Improvements), including by improving efficiency, effectiveness, productivity or customer service or by reducing any costs or related risks." (Telecom Corporation of New Zealand Limited \& Crown Fibre Holdings Limited, 2011). However, undertakings against these risks are not discussed but problems should be resolved based on reporting and regular consultation (7.3).

Interestingly, there is a part in the Network Agreement which obligates Chorus to "proactively identify, assess and monitor operational, technical, commercial and other risks in relation to the Network and take action to minimise those risks to a level that is reasonable in the circumstances (including by the preparation of contingency plans) (Telecom Corporation of New Zealand Limited \& Crown Fibre Holdings Limited, 2011).

With respect to demand and revenue risks, the agreements specifies that for Chorus should provide “industry's best practice fibre optic communications infrastructure network in the Coverage Area and generate widespread uptake of services (including Layer 1 Services and Layer 2 Services) in the Coverage Area." However, the uptake of services based on fiber will be the task of independent retail service providers, they will assume the demand risk.

Chorus and CFH have been careful in negotiating the details of the financial agreement to mitigate different forms of financial risk. A first requirement in the Interim Period Agreement was, the requirement of structural separation, i.e. the splitting up of one company "focusing on the supply of fixed access and aggregation services in New Zealand and the other [..] focusing on fixed, mobile and ICT products and services." (Crown Fibre Holdings Limited \& Telecom Corporation of New Zealand 
Limited, 2011). Furthermore, the document tried to exclude political risks (e.g. change in taxation or legislation) from the risk portfolio of the company (7.2 Modifications to Bill or Tax Rulings). In addition, the agreement specified that the regulatory risks will be the responsibility of the public party. In this context, the document characterized these risks in the following way: "Officials advised us that the reason for introducing a forbearance period is to achieve lower prices, by removing the risk premium; that is, investors would be more comfortable with lower returns initially because there is no risk that these returns would be undercut by regulation for the duration of the forbearance period". As a result a number of undertakings have been defined with respect to nondiscrimination, unbundling, open access and the LFC dealings in relation to UFP partners at armslength (Crown Fibre Holdings Limited \& Telecom Corporation of New Zealand Limited, 2011).

In contrast to the agreements with LFCs, the contracts between Chorus and CFH have been more detailed with respect to a number of anticipated risks (e.g. technical risks) and statutory (or political) risks. As Chorus has a different company structure and strategy, in particular with respect to legacy assets, the definition of financial risks and residual value risk has been much more prominent compared to the contracts drawn up for the LFCs. However, LFCs and Chorus will be exposed to demand and revenue risks as these risks are allocated to retail service providers.

In addition, the current pricing structure as suggested by retail service providers does not allow for consumers to distinguish between the advantages of having fiber based services compared to using (only) bitstream access. It currently seems that fiber access is considered by consumers as just another higher segment in the existing broadband market based on speed (see Appendix 4).

\section{$5 \quad$ Summary and Conclusions}

The theoretical discussion of literature on public private interplay showed that PPIs can have rather different and a complex forms ranging from pure market transactions to strictly vertically integrated forms. As an alternative way of fostering private investment in the broadband development, the risks posed by these ventures are in different ways allocate to the private and public stakeholders involved. The key for the success of these ventures lies in the ability to allocate these risks to the party which best can bare these risks.

In the context of emergence of next generation networks in 2008, PPIs have increasingly been affected by the legislative and regulatory framework in in New Zealand and Europe. The differences in dealing with PPIs between New Zealand and Europe are related to the way the next generation 
access (NGA) technologies are implemented. In Europe, experiences in dealing with different migration paths towards NGA rollout are building up partly included in the Commission's 2009 Broadband Guidelines but also in new existing case law. In New Zealand, new insights can be gained from the effects of separation on NGA rollout.

With respect to the structure and evolution of the broadband sector, New Zealand has - after a period of slow growth of broadband - taken the opportunity to foster NGA growth based on the UFB initiative. As the initiative has been considered as successful in terms of providing fiber to the curb after the first year of UFB implementation, actual take up of fiber based connections of subscribers is still trailing.

In examining the structure of the agreements between Chorus and CFH as well as between the LFCs and $\mathrm{CFH}$, the allocation of the different risks between private firms and $\mathrm{CFH}$ has been analyzed. If the risks are wrongly allocated, the incentive structure of the ventures is insufficient for the parties involved and the output of the ventures in terms of quantity and quality of service can be negatively affected. In the paper, it has been found that for the three joint ventures a number of risks are specified in particular with respect to statutory and political risks (responsibility of CFH and different ministries); and design, construction, time schedule, and operation risk (taken by the LFC). For a number of other risks (like financial risks or, technical risks), they are not sufficiently specified yet. The contracts between Chorus and CFH have been different with respect to a number of anticipated risks (e.g. technical risks), statutory (or political) risks, financial risks and residual value risks. We furthermore found that LFCs and Chorus will be exposed to demand and revenue risks because these risks are allocated to retail service providers. In addition, it seems that that due to the sharing of risk between different parties, the joint venture form of governance is more appropriate compared to the contractual arrangements between Chorus and CFH. 


\section{Literature}

Amy Adams. (2012). UFB exceeds year one target. New Zealand Government Wellington: 2 August 2012.

CEU. (2010). A Digital Agenda for Europe COM(2010) 245 final/2.

Commerce Commission New Zealand. (2008). Discussion Paper on Next Generation Networks. Wellington: Commerce Commission New Zealand 24 December 2008.

Commerce Commission New Zealand. (2009). Next Generation Networks. Strategic Issues and Key Themes. Wellington: Commerce Commission New Zealand 6 May 2009.

Commerce Commission New Zealand. (2012a). Annual Telecommunications Monitoring Report 2011. Wellington: Commerce Commission New Zealand.

Commerce Commission New Zealand. (2012b). Definition of NGA. http://www.comcom.govt.nz/next-generation-networks-2/.

Communications Day. (2012). NZ UFB blitzes year-one rollout target: Communications Day 3 August 2012.

Crown Fibre Holdings Limited. (2011). New Zealand's Broadband Vision. Retrieved 8-03-2012, from http://www.crownfibre.govt.nz/about-us/new-zealand\%E2\%80\%99s-broadband-vision.aspx

Crown Fibre Holdings Limited. (2012a). Chorus announces next towns to get UFB. 8 March 2012.

Crown Fibre Holdings Limited. (2012b). Ultrafast Fibre reaches milestone in fibre rollout to schools: 21 March 2012.

Demsetz, H. (1968). Why Regulate Utilities. Journal of Law and Economics, 11(1), 55-65.

European Commission Competition Directorate-General. (2012). Commission decisions on State aid to broadband Brussels: European Commission

Falch, M., \& Henten, A. (2010). Public private partnerships as a tool for stimulating investments in broadband. Telecommunications Policy, 34(9), 496-504.

Funston, K. (2010). National Broadband Deployment Approach: New Zealand. Presented at WIK Conference "National Strategies for Ultrabroadband Infrastructure Deployment: Experiences and Challenges: Radisson Blu Hotel, Berlin", 26-27 April 2010.

Gomez-Barroso, J. L., \& Feijóo, C. (2010). A Conceptual Framework for Public-Private Interplay in the Telecommunications Sector. Telecommunications Policy, forthcoming.

Howell, B. (2010). Structural Separation Models and the Provision of 'Dark Fibre' for Broadband Networks: the case of CityLink. ISCR Working Paper August 2010.

Howell, B., Meade, R., \& O'Connor, S. (2010). Structural Separation versus Vertical Integration: Lessons for Telecommunications from Electricity Reforms. Telecommunications Policy, 34(7), 392-403.

Huigen, J., \& Cave, M. (2008). Regulation and the promotion of investment in next generation networks-A European dilemma. Telecommunications Policy, 32(11), 713-721.

infonews.co.nz. (2012). New Zealand going nowhere ultra-fast. 19 July 2012: infonews.co.nz.

Jock, G. (2010). Take your partners: Public private interplay in Australian and New Zealand plans for next generation broadband. Telecommunications Policy, 34(9), 540-549.

Lehr, W., Sirbu, M., \& Gillett, S. (2006). Wireless Is Changing the Policy Calculus for Municipal Broadband. Government Information Quarterly, 23, 435-453.

Neumann, K.-H., Schäfer, R. G., Doose, A. M., \& Elixmann, D. (2011). Study on the Implementation of the existing Broadband Guidelines Bad Honnef 7 December 2011.

Northpower. (2012). Ultra-Fast broadband rolled out in Whangarei. NZ HERALD

Northpower, \& Crown Fibre Holdings Limited. (2011). Network Infrastucture Project Agreement Auckland: Bell Gully 10 December 2010.

Nucciarelli, A., Sadowski, B., \& Achard, P. (2010). Emerging models of public-private interplay for European broadband access: Evidence from the Netherlands and Italy. Telecommunications Policy, 34(9), 513-527. 
Nucciarelli, A., \& Sadowski, B. M. (2010). The Italian way to functional separation: An assessment of background and criticalities. Telecommunications Policy, 34(7), 384-391.

OECD. (2012). Broadband Statistics. Paris: OECD.

Picot, A., \& Wernick, C. (2007). The Role of Government in Broadband Access. Telecommunications Policy, 31, 660-674.

Sadowski, B., Nucciarelli, A., \& de Rooij, M. (2009). Providing Incentives for Private Investment in Municipal Broadband Networks: Evidence from the Netherlands. Telecommunications Policy, 33(10-11), 582-595.

Telecom Corporation of New Zealand Limited, \& Crown Fibre Holdings Limited. (2011). Network Infrastructure Project Agreement. Auckland: Bell Gully 24 July 2011.

Telecommunications Carrier Forum. (2012). CFH's Future Role. 13 February 2012.

The Domininon Post. (2012). Broadband uptake rises. 21 July 2012.

Williamson, O. E. (1976). Franchise Bidding for Natural Monopolies-in General and with Respect to CATV. The Bell Journal of Economics, 7(1), 73-104. 


\begin{tabular}{|c|c|c|c|c|c|c|c|c|}
\hline $\begin{array}{l}\text { Country } \\
\text { Code }\end{array}$ & Country & $\begin{array}{r}\text { PSTN/ } \\
100 \\
\text { inh } \\
2000 \\
\end{array}$ & Rank & $\begin{array}{r}\text { PSTN/ } \\
100 \\
\text { inh } \\
2011 \\
\end{array}$ & Rank & $\begin{array}{r}\text { GAGR } \\
2002- \\
2005\end{array}$ & $\begin{array}{r}\text { GAGR } \\
2005- \\
2008\end{array}$ & $\begin{array}{r}\text { GAGR } \\
2008- \\
2011\end{array}$ \\
\hline AUS & Australia & 52.44 & 15 & 46.63 & 13 & -0.01 & -0.02 & 0.03 \\
\hline AUT & Austria & 49.93 & 17 & 40.27 & 24 & -0.01 & -0.03 & 0.01 \\
\hline BEL & Belgium & 49.49 & 18 & 43.06 & 18 & -0.01 & 0.00 & -0.01 \\
\hline CAN & Canada & 67.95 & 6 & 47.86 & 12 & -0.03 & 0.00 & -0.03 \\
\hline CZE & Czech Republic & 37.80 & 28 & 20.90 & 28 & -0.01 & -0.02 & -0.01 \\
\hline DNK & Denmark & 71.82 & 2 & 45.13 & 16 & -0.03 & -0.06 & -0.03 \\
\hline EST & Estonia & 38.14 & 27 & 35.10 & 25 & 0.01 & -0.02 & 0.01 \\
\hline FIN & Finland & 55.07 & 13 & 20.06 & 29 & -0.02 & -0.03 & -0.04 \\
\hline FRA & France & 57.56 & 10 & 55.92 & 5 & 0.02 & 0.01 & -0.01 \\
\hline DEU & Germany & 60.98 & 8 & 63.05 & 1 & -0.02 & 0.03 & -0.10 \\
\hline GRC & Greece & 51.51 & 16 & 49.91 & 9 & -0.06 & -0.06 & 0.00 \\
\hline HUN & Hungary & 37.20 & 29 & 29.43 & 27 & 0.00 & 0.01 & -0.01 \\
\hline ISL & Iceland & 69.82 & 3 & 58.43 & 4 & 0.00 & 0.00 & 0.02 \\
\hline $\mathrm{IRL}$ & Ireland & 48.16 & 21 & 45.22 & 15 & 0.00 & -0.04 & -0.01 \\
\hline ISR & Israel & 49.44 & 19 & 46.28 & 14 & -0.02 & -0.02 & -0.02 \\
\hline ITA & Italy & 47.65 & 22 & 34.64 & 26 & 0.01 & 0.02 & -0.01 \\
\hline JPN & Japan & 49.28 & 20 & 51.06 & 8 & 0.01 & 0.01 & 0.02 \\
\hline KOR & Korea (Rep. of) & 56.24 & 12 & 60.90 & 2 & -0.01 & 0.02 & -0.01 \\
\hline LUX & Luxembourg & 57.15 & 11 & 54.10 & 6 & -0.02 & -0.03 & 0.07 \\
\hline NLD & Netherlands & 62.34 & 7 & $43.53^{*}$ & 17 & -0.01 & -0.04 & 0.05 \\
\hline NZL & New Zealand & 47.46 & 23 & 42.59 & 21 & -0.02 & 0.00 & 0.02 \\
\hline NOR & Norway & 53.46 & 14 & 42.71 & 20 & 0.00 & 0.02 & -0.01 \\
\hline POL & Poland & 28.58 & 31 & 18.07 & 31 & -0.01 & -0.01 & 0.03 \\
\hline PRT & Portugal & 41.80 & 25 & 42.33 & 23 & -0.02 & -0.03 & 0.02 \\
\hline SVK & Slovak Republic & 31.42 & 30 & 19.30 & 30 & -0.01 & 0.00 & -0.08 \\
\hline SVN & Slovenia & 39.56 & 26 & 42.89 & 19 & 0.00 & -0.05 & 0.02 \\
\hline ESP & Spain & 42.45 & 24 & 42.34 & 22 & -0.01 & 0.00 & -0.05 \\
\hline SWE & Sweden & 68.35 & 4 & 48.72 & 10 & -0.04 & 0.02 & -0.03 \\
\hline $\mathrm{CHE}$ & Switzerland & 73.04 & 1 & 60.82 & 3 & 0.06 & -0.01 & -0.04 \\
\hline GBR & United Kingdom & 59.84 & 9 & 53.24 & 7 & -0.01 & -0.01 & -0.02 \\
\hline USA & United States & 68.15 & 5 & 47.91 & 11 & -0.02 & -0.02 & -0.01 \\
\hline \multicolumn{2}{|c|}{ Average OECD } & 52.39 & & 43.62 & & -0.01 & -0.01 & 0.03 \\
\hline
\end{tabular}

(Source: OECD/ITU 2012; Data: always 30-06, PSTN measured in in fixed telephone subscriptions; * data for 2010 )

Appendix 1: Growth rate of the public switched network (PSTN) in selected OECD countries 


\begin{tabular}{|c|c|c|c|c|c|c|c|c|c|}
\hline $\begin{array}{l}\text { Country } \\
\text { Code }\end{array}$ & Country & $\begin{array}{c}\text { BB/ } \\
100 \\
\text { inh. } \\
(2000)\end{array}$ & $\mathbf{R}$ & $\begin{array}{c}\mathrm{BB} / \\
100 \\
\text { inh. } \\
(2011)\end{array}$ & $\mathbf{R}$ & $\begin{array}{c}\text { GAGR } \\
2002- \\
2005\end{array}$ & $\begin{array}{c}\text { GAGR } \\
2005- \\
2008\end{array}$ & $\begin{array}{c}\text { GAGR } \\
2008- \\
2011\end{array}$ & $\begin{array}{c}\text { Growth } \\
2011- \\
2012\end{array}$ \\
\hline AUS & Australia & $0.63^{*}$ & 14 & 23.93 & 21 & 0.67 & 0.07 & 0.01 & 0.05 \\
\hline AUT & Austria & 2.38 & 5 & 26.49 & 18 & 0.27 & 0.05 & 0.07 & 0.07 \\
\hline BEL & Belgium & 1.42 & 7 & 32.95 & 8 & 0.25 & 0.05 & 0.05 & 0.05 \\
\hline CAN & Canada & 4.60 & 2 & 32.02 & 12 & 0.19 & 0.05 & 0.03 & 0.08 \\
\hline CZE & $\begin{array}{l}\text { Czech } \\
\text { Republic }\end{array}$ & 0.02 & 27 & 15.66 & 29 & 0.38 & 0.06 & 0.04 & 0.04 \\
\hline DNK & Denmark & 1.25 & 9 & 38.21 & 3 & 1.61 & 0.12 & -0.02 & 0.08 \\
\hline EST & Estonia & $1.28^{*}$ & 8 & 27.14 & 17 & 0.35 & 0.11 & 0.04 & 0.02 \\
\hline FIN & Finland & 0.68 & 13 & 29.50 & 14 & 0.31 & 0.03 & 0.02 & 0.02 \\
\hline FRA & France & 0.33 & 16 & 36.12 & 6 & 0.42 & 0.08 & 0.05 & 0.04 \\
\hline$\overline{\mathrm{DEU}}$ & Germany & 0.32 & 17 & 32.47 & 11 & 0.40 & 0.03 & 0.07 & 0.08 \\
\hline GRC & Greece & $0.09^{* \star *}$ & 24 & 21.64 & 27 & 0.44 & 0.03 & 0.00 & 0.01 \\
\hline HUN & Hungary & 0.03 & 26 & 22.16 & 25 & 0.55 & 0.09 & 0.06 & 0.07 \\
\hline ISL & Iceland & 0.84 & 10 & 33.92 & 7 & 0.64 & 0.07 & 0.04 & 0.07 \\
\hline $\mathrm{IRL}$ & Ireland & $0.27^{* *}$ & 28 & 22.08 & 26 & 0.98 & 0.33 & 0.13 & 0.09 \\
\hline ISR & Israel & 0.00 & 29 & 23.80 & 22 & 0.56 & 0.09 & 0.07 & 0.07 \\
\hline ITA & Italy & 0.20 & 20 & 22.84 & 24 & 1.35 & 0.08 & 0.07 & 0.06 \\
\hline JPN & Japan & 0.68 & 12 & 27.36 & 16 & 0.34 & 0.04 & 0.01 & 0.03 \\
\hline KOR & $\begin{array}{l}\text { Korea (Rep. } \\
\text { of) }\end{array}$ & 8.42 & 1 & 36.91 & 4 & 0.52 & 0.04 & 0.02 & 0.02 \\
\hline LUX & Luxembourg & 0.00 & 30 & 32.90 & 9 & 0.68 & 0.07 & 0.05 & 0.06 \\
\hline NLD & Netherlands & 1.64 & 6 & 38.74 & 2 & 0.25 & 0.03 & 0.04 & 0.02 \\
\hline NZL & New Zealand & 0.12 & $\underline{22}$ & 25.78 & $\underline{19}$ & 0.04 & 0.02 & 0.04 & 0.04 \\
\hline NOR & Norway & 0.52 & $\overline{15}$ & 36.55 & $\overline{5}$ & 0.86 & 0.10 & 0.04 & 0.01 \\
\hline $\mathrm{POL}$ & Poland & 0.00 & 31 & 14.36 & 30 & 0.37 & 0.03 & 0.03 & 0.02 \\
\hline PRT & Portugal & 0.24 & 19 & 20.95 & 28 & 0.48 & 0.06 & 0.03 & 0.04 \\
\hline SVK & $\begin{array}{l}\text { Slovak } \\
\text { Republic }\end{array}$ & $0.08^{\star \star}$ & 25 & 13.65 & 31 & 0.65 & 0.18 & 0.06 & 0.04 \\
\hline SVN & Slovenia & $0.28^{*}$ & 18 & 24.75 & 20 & 0.67 & 0.08 & 0.08 & 0.11 \\
\hline ESP & Spain & 0.19 & 21 & 23.52 & 23 & 0.45 & 0.03 & 0.09 & 0.05 \\
\hline SWE & Sweden & 2.81 & 3 & 31.77 & 13 & 1.58 & 0.14 & 0.09 & 0.08 \\
\hline $\mathrm{CHE}$ & Switzerland & 0.79 & 11 & 39.20 & 1 & 0.36 & 0.11 & 0.04 & 0.05 \\
\hline GBR & $\begin{array}{l}\text { United } \\
\text { Kingdom }\end{array}$ & 0.09 & 24 & 32.74 & 10 & 0.32 & 0.04 & 0.01 & 0.00 \\
\hline USA & United States & 2.50 & 4 & 28.75 & 15 & 0.27 & 0.06 & 0.04 & 0.05 \\
\hline $\begin{array}{l}\text { Average } \\
\text { OECD }\end{array}$ & & 1.05 & & 28.03 & & 0.56 & 0.08 & 0.05 & 0.03 \\
\hline
\end{tabular}

(Data: OECD/ITU 2012; always 30-06; data for ${ }^{\star} 2001$; data for ${ }^{* \star} 2002$, data for ${ }^{* \star} 2003$ )

Appendix 2: Growth rate of the broadband connections in selected OECD countries 
Appendix 3: Rollout Plan Rural Broadband Initiative 2011 - 2015

\begin{tabular}{|c|c|c|c|c|c|}
\hline Year & Education & Health & Public Libraries & $\begin{array}{l}\text { Number of } \\
\text { new cell sites } \\
\text { to receive RBI } \\
\text { fibre }\end{array}$ & $\begin{array}{l}\text { Fibre to the } \\
\text { node* } \\
986 \text { cabinets } \\
5 \mathrm{Mbps} \\
\text { coverage }\end{array}$ \\
\hline 2011 & $\begin{array}{l}71,300 \text { pupils in } \\
520 \text { schools }\end{array}$ & $\begin{array}{l}5 \text { hospitals } \\
5 \text { health } \\
\text { centres }\end{array}$ & & 21 & $\begin{array}{l}+17,400 \text { lines } \\
27 \%\end{array}$ \\
\hline 2012 & $\begin{array}{l}48,000 \text { pupils in } \\
331 \text { schools }\end{array}$ & $\begin{array}{l}27 \text { hospitals } \\
5 \text { health } \\
\text { centres }\end{array}$ & 63 & 45 & $\begin{array}{l}+30,200 \text { lines } \\
37 \%\end{array}$ \\
\hline 2013 & $\begin{array}{l}23,900 \text { pupils in } \\
170 \text { schools }\end{array}$ & 11 hospitals & 120 & 52 & $+25,000$ lines \\
\hline 2014 & $\begin{array}{l}3,150 \text { pupils in } 70 \\
\text { schools }\end{array}$ & & & 34 & \\
\hline 2015 & $\begin{array}{l}22 \text { pupils in } 1 \\
\text { school }\end{array}$ & & & 2 & $\begin{array}{l}+12,500 \text { lines } \\
57 \%\end{array}$ \\
\hline Total & $\begin{array}{l}146,350 \text { pupils in } \\
1092 \text { schools }\end{array}$ & $\begin{array}{l}43 \text { hospitals } \\
10 \text { health } \\
\text { centres }\end{array}$ & 183 libraries & 154 cell sites & $\begin{array}{l}104,700 \text { lines } \\
57 \%\end{array}$ \\
\hline
\end{tabular}

* Fibre to the node extends the reach of exchanges. Thousands of mini-exchanges or cabinets are installed in towns and suburbs, which are then linked to the local exchange with fibre optic cable

Source: Ministry of Economic Development accessed 11-08-2012 http://www.med.govt.nz/sectorsindustries/technology-communication/fast-broadband/rural-broadband-initiative/roll-out-schedule 


\section{Appendix 4: Willingness to pay for UFB Fibre-based services (Example of InSpireNet)}

InSpireNet is an ISP providing retail consumer broadband based on fibre in Palmerston North and surrounding areas as well as Bitstream access nationwide.

\begin{tabular}{|l|l|}
\hline \multicolumn{2}{|l|}{ MetroLAN Fiber Based Service $100 \mathrm{Mbit} / \mathrm{s}$} \\
\hline Cap & Price \\
\hline $20 \mathrm{~GB}$ & NZ\$135/mth $(\$ 107)$ \\
\hline $40 \mathrm{~GB}$ & NZ\$155/mth $\$ 123)$ \\
\hline $100 \mathrm{~GB}$ & NZ\$195/mth $\mathbf{1 5 4 )}$ \\
\hline $200 \mathrm{~GB}$ & NZ\$270/mth $\$ 214)$ \\
\hline $400 \mathrm{~GB}$ & NZ\$345/mth (\$273) \\
\hline
\end{tabular}

(* Data www.inspire.co.nz accessed 24-07-2012)

Table 1: Prices for Fiber-based services by Inspire

\section{Bitstream FS-FS 16Mbps}

\begin{tabular}{|c|c|}
\hline Cap & Price \\
\hline $20 \mathrm{~GB}$ & NZ\$85/mth (\$67) \\
\hline $50 \mathrm{~GB}$ & NZ\$95/mth (\$75) \\
\hline $100 \mathrm{~GB}$ & NZ\$135/mth (\$107) \\
\hline $200 \mathrm{~GB}$ & NZ\$200/mth (\$158) \\
\hline $500 \mathrm{~GB}$ & NZ\$345/mth (\$273) \\
\hline
\end{tabular}

(* Data www.inspire.co.nz accessed 24-07-2012)

Table 2: Prices for Bit-stream services by Inspire 